\title{
Abundance and prey capture success of Common Terns (Sterna hirundo) and Pied Kingfishers (Ceryle rudis) in relation to water clarity in south-east coastal Ghana
}

\author{
Lars H. Holbech ${ }^{1 *}$, Francis Gbogbo ${ }^{1}$ and Timothy Khan Aikins ${ }^{1,2}$
}

\begin{abstract}
Background: Water clarity may negatively influence rate of plunge diving and prey capture success of piscivorous plunge-diving birds, and therefore has implications for their conservation in polluted urban wetlands. We studied the relationship between water clarity and the abundance and prey capture success of Pied Kingfishers (Ceryle rudis) and Common Terns (Sterna hirundo) in two polluted coastal waters of south-east Ghana—-the Weija Lake and Densu Delta Ramsar Site.

Methods: On each wetland, data on abundance and prey capture success of plunge-divers were collected in four spatio-temporal quadrats of $100 \mathrm{~m} \times 100 \mathrm{~m}$ and analysed with concurrent measurements of water quality parameters using GLM regression with Pearson's correlation coefficients.

Results: Mean prey capture success of Pied Kingfishers (34.7 $\pm 13.1 \%$ ) and Common Terns (35.3 $\pm 11.0 \%$ ) were similar but the two species responded differently to water clarity. The abundance of Common Terns was significantly higher in less transparent/more turbid water while that of Pied Kingfishers showed no significant relationship with turbidity and transparency. In contrast, the prey capture success of Common Terns was neither related to transparency nor turbidity, as opposed to that of Pied Kingfishers which was significantly higher in more turbid/less transparent waters. Correlations between capture success and bird abundance, as well as capture attempts were insignificant, suggesting that increased fish abundance associated with cloudy water may not necessarily promote higher abundance and capture success of foraging birds. Thus, when foraging in less transparent water, capture success may depend more on predator avoidance by fish prey than lower prey detectability of foraging birds.
\end{abstract}

Conclusion: Within a gradient of 15-51 cm transparency studied, lower water clarity did not constrain prey capture success of Common Terns and Pied Kingfishers. Further studies on the foraging ecology of plunge-divers in coastal Ghana are however required to make firm conclusions on the relationship between water clarity and foraging birds and fish prey abundances, as well as capture success.

Keywords: Coastal Ghana, Common Tern, Pied Kingfisher, Prey capture success, Water turbidity and transparency

\footnotetext{
${ }^{*}$ Correspondence: I.holbech@gmail.com

${ }^{1}$ Department of Animal Biology and Conservation Science, University

of Ghana, P.O. Box LG 67, Legon, Accra, Ghana

Full list of author information is available at the end of the article
} 


\section{Background}

Piscivorous plunge-diving birds include boobies, gannets, pelicans, tropicbirds, terns, dippers, kingfishers, fish eagles and ospreys. These forage on fast moving prey by diving into water from flight and therefore using the kinetic energy from the momentum of the dive to counteract natural buoyancy (Ropert-Coudert et al. 2004, 2009). Taylor (1983) described three types of plunge diving as 'contact dipping,' 'partial plunge-dive' and 'full plunge-dive.' During contact dipping, the bird remains in flight throughout and uses the bill which is the only part touching the water to snatch the prey from the surface (e.g. Sandwich Tern Thalasseus sandvicensis and Shining Blue Kingfisher Alcedo quadribrachys). In partial plungedive, birds adjust their descent and level out partially before reaching the water so that entry is made at an angle of approximately 45 degrees and only the head and the chest are submerged (e.g. Osprey Pandion haliaetus and Royal Tern Thalasseus maximus). In full plunge-dive, the bird descends to and enters the water vertically or almost so $\left(70-90^{\circ}\right)$ and becomes completely submerged to capture prey. Throughout the descent and entry of the water the wings are partially folded and variably held close against the body (e.g. Brown Pelican Pelecanus occidentalis and Northern Gannet Sula bassana). The skill of plunge-diving takes several years to develop and therefore, its success is dependent upon age, experience and condition of the bird (Dunn 1972b; Buckley and Buckley 1974; Elliot 1992; Shealer and Burger 1995; Watson and Hatch 1999).

The abundance of plunge-divers in a given area depends on both interspecific interactions related to prey density and functional response (Reyer et al. 1988; Davoren et al. 2003; Enstipp et al. 2007), as well as competition from other predators (Safina 1990a, b; Safina and Burger 1985), but also the ability of birds to capture prey, and their prey capture rate and success (Eriksson 1985). The rate and success of prey capture, among other factors (e.g. condition and experience of birds), depend primarily on the visibility of prey (Henkel 2006; Strod et al. 2008; Stempniewicz et al. 2013), as well as the prey's predator avoidance behaviour (Katzir and Camhi 1993; Abrahams and Kattenfeld 1997; Sohel and Lindström 2015). Theoretically therefore, water clarity may have an effect on both the visibility of prey for the predator, but also on the visibility of the predator by the prey (Abrahams and Kattenfeld 1997). As such, whereas it may be easier for plunge-divers to detect moving prey in clearer waters (Eriksson 1985), it may also be relatively easier for the prey to detect the approaching danger and escape the attack in less turbid water bodies (Katzir and Camhi 1993; Abrahams and Kattenfeld 1997; Sohel and Lindström 2015).
Empirical evidence indicates that the relationship between water clarity and the abundance and capture success of plunge-diving birds is ambiguous and shows high variation across species, foraging mode (i.e. contact dip or plunge-type) and habitats around the world. Haney and Stone (1988) reported a non-significant correlation between the abundance of Little Tern (Sterna albifrons) and water clarity compared to Safina and Burger (1988) in which the density of Common Tern flocks was negatively correlated with water clarity. In contrast, Haney (1991) found Common Loons (Gavia immer) to be less frequently foraging in turbid waters. Likewise, Briggs et al. (1988) found that Cassin's Auklets (Ptycoramphus aleuticus) primarily forage in clear waters, whereas Common Murres (Uria aalge) use clear and turbid waters equally. These studies are predominantly from the temperate zone, but in the Afrotropics, relatively little is known about species-specific responses to water clarity, with most of the work emanating from South African coastal waters (e.g. Cyrus 1991; Braby et al. 2011; Russell et al. 2014). Few studies exist from West Africa (e.g. Brenninkmeijer et al. 2002), and despite the fact that Ghana falls within the boundaries of the EastAtlantic and Mediterranean flyways, and is frequented by a large number of migratory waterbirds (Gbogbo 2007), we found no published studies on the foraging ecology of migratory or resident plunge-divers in Ghana.

To protect coastal wetlands and waterbirds in Ghana, several protected wetland areas (Ramsar sites) have been established (Piersma and Ntiamoa-Baidu 1995; Ntiamoa-Baidu et al. 2000). However, as a result of increasing urbanisation, human activities continue to increase within and around protected as well as unmanaged wetlands in Ghana, with associated negative impacts on wetland habitats and waterbirds (Gbogbo and Attuquayefio 2010; Lamptey and Ofori-Danson 2014). In particular, the discharge of sewage and agro-chemicals into these wetlands decreases water quality, thereby affecting abundance and availability of fish and macro-invertebrates, and thus impacting directly on the foraging ecology and survival of waterbirds (Ahulu et al. 2006; Gbogbo et al. $2008,2013)$. As such it is important to evaluate the ecological impacts of changing water quality on the foraging success of plunge-diving birds in wetlands that serve as their main foraging habitats. In this study, we assessed the effect of water turbidity/transparency on the abundance and prey capture success of two species of piscivorous plunge-divers-the Pied Kingfisher (Ceryle rudis) (a partial plunge-diver) and Common Tern (Sterna hirundo) (a contact dipper). Both species are attracted to estuarine habitats and capable of utilising inland as well as offshore waterbodies. We anticipated that the prey capture success of these plunge-divers would invariably 
decrease with increasing water turbidity, and as a result, the birds would be more closely associated with clearer waters. Since plunge-diving birds constitute an import component of wetland ecosystems across West Africa, the implications for this study to the management and conservation of wetlands and piscivorous plunge-diving birds cannot be overemphasised.

\section{Methods}

\section{Study area}

The study was carried out at two sites: the Densu Delta Ramsar Site (hereafter only Densu) and Weija Lake (hereafter only Weija) in the Greater Accra Region (Fig. 1). The two areas are less than $8 \mathrm{~km}$ apart and situated in a tropical coastal savannah zone with a monthly average temperature and rainfall of $c .27^{\circ} \mathrm{C}$ and $c .65 \mathrm{~mm}$ respectively (Quarcoopome and Amevenku 2010). Rainfall pattern is bimodal, with two rainfall peaks in June and September, while dry periods span between December and March (Quarcoopome and Amevenku 2010). Both areas are situated close to Accra in heavily populated areas including Dansoman, Mallam, Kwashieman and Kasoa.

Densu $\left(5^{\circ} 31^{\prime} 06^{\prime \prime} \mathrm{N}, 0^{\circ} 18^{\prime} 49^{\prime \prime} \mathrm{W}\right)$ covers an area of about $50 \mathrm{~km}^{2}$ and comprises the saltpans, sand dunes, flood plains and the lowest part of the $c .2600 \mathrm{~km}^{2}$ Densu River catchment water course area where it joins the Gulf of
Guinea (WRC Ghana 2007). About 60 species of waterbirds have been recorded at this site, with an estimated maximum number of $c$. 35,000 birds (Grimble et al. 1998; Gbogbo and Attuquayefio 2010). The site is particularly important for roosting terns ( $>20,000$ birds) and is the second most important site in Ghana for the rare Roseate Tern (Sterna dougallii) (Gbogbo and Attuquayefio 2010; BirdLife International 2018). About $40 \%$ of Densu has been developed into saltpans for industrial salt production by the Pambros Salt Company (Gbogbo 2007), and other important economic activities include sand mining, clay and stone quarrying, as well as fishing and farming (WRC Ghana 2007).

Weija $\left(5^{\circ} 34^{\prime} 43^{\prime \prime} \mathrm{N} ; 0^{\circ} 21^{\prime} 39^{\prime \prime} \mathrm{W}\right)$ is a man-made reservoir created in 1977-1978 by the now Ghana Water Company Ltd., through the damming of the Densu River mainly to satisfy the demand for potable water supply. The reservoir takes its source from the Atewa-Atwiredu mountain range in the Eastern Region of Ghana (Asante et al. 2008). Weija is $c .14 \mathrm{~km}$ long, $2.2 \mathrm{~km}$ wide and has a total surface area of $c .33 .6 \mathrm{~km}^{2}$ with a mean depth of $5 \mathrm{~m}$ (Quarcoopome and Amevenku 2010). The main economic activities in the catchment area are fishing and crop farming, with major crops such as maize, cassava, sugar-cane and vegetables (Ansa-Asare and Asante 1998). Large amounts of untreated domestic waste water

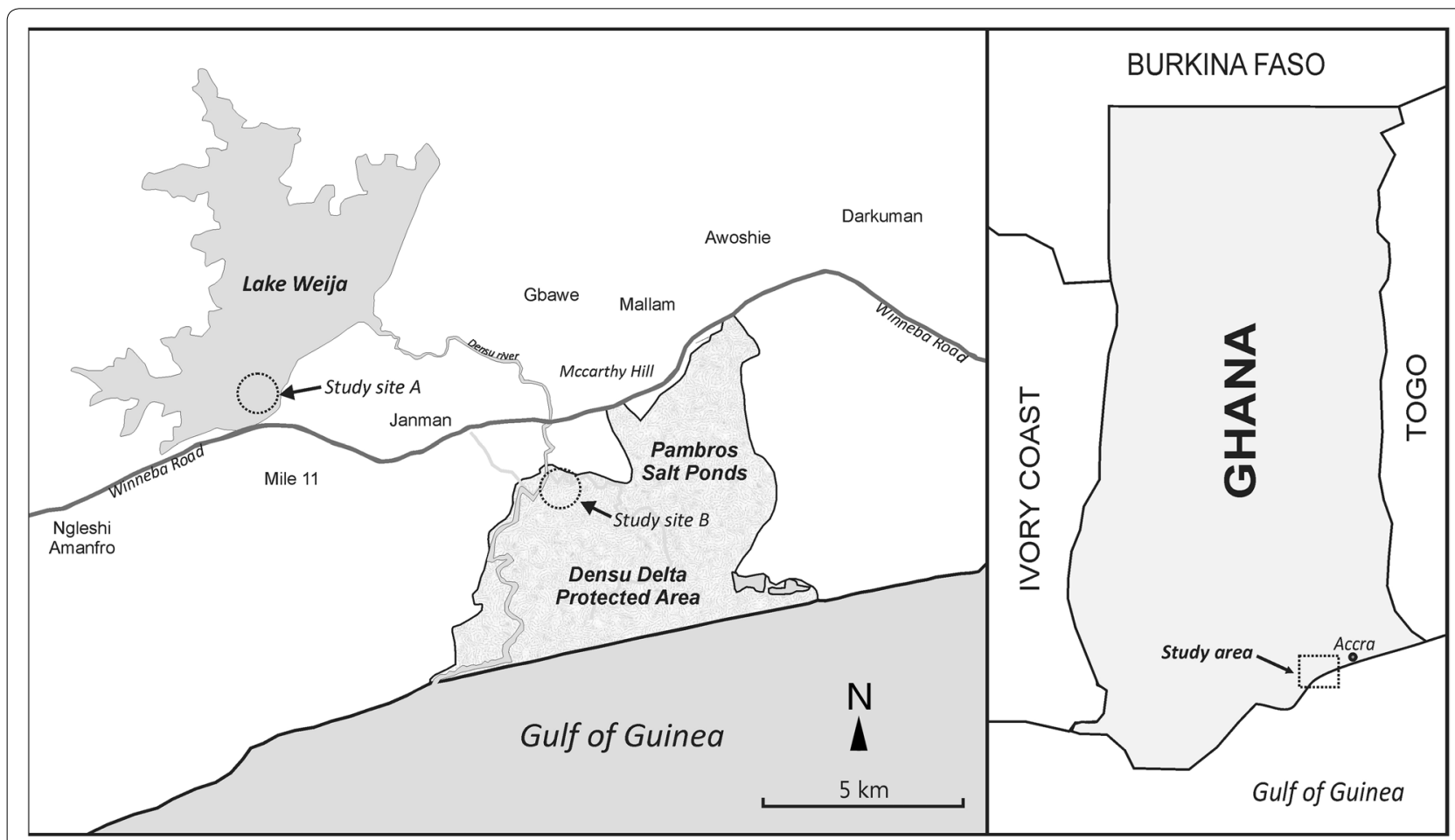

Fig. 1 Map of the study area, and two study sites (broken circles); a Lake Weija, b Densu Delta Ramsar Site (Protected Area), south eastern coastal Ghana. The map was adapted from Google Maps ${ }^{\circledR}$ 
are discharged into Weija which also serves as one of Accra's important sources of potable water (Asante et al. 2008).

\section{Data collection Sample design}

At each of the two wetlands, four sample plots of $c .1$ ha (c. $100 \mathrm{~m} \times 100 \mathrm{~m}$ quadrat) were selected for the study. Sampling plots consisted of open water surface areas only and their demarcations were guided by natural and artificial landscape features adjoining the selected waterbodies (e.g. bays, creeks, reed beds, buildings, canoes, pillars, shelters) as described by Gbogbo and Attuquayefio (2010). Within each of these 1-ha plots, various water quality parameters were obtained prior to concurrent observations of foraging plunge-divers. As the water quality parameters varied with time, bird observations and water sample collections were made on the same days, producing matched data on birds and water quality parameters in spatio-temporal data sample points of each 1-ha plot. Bird observations and water quality measurements were done on three days for both Densu (19th March, 31st March and 18th April, 2015) and Weija (20th March, 1st April and 17th April, 2015), i.e. within the transition between end of the major dry and beginning of the major wet season.

\section{Water quality parameters}

The transparency of the water column in each 1-ha plot was determined with a standard 30-cm diameter, black/ white Perspex Secchi disc and a rope. It was lowered on the shadow side of a canoe until it was no longer visible. It was then gently raised until the disc became visible again and the value recorded after measuring the rope length with a tape measure. To avoid measurement errors due to bubbles or foam, measurements were delayed at the spot until the views were clear (Baptist and Leopold 2010). In order to obtain the mean transparency for each 1-ha plot on a specific day, measurements were taken at three haphazardly chosen spots which were at least $30 \mathrm{~m}$ apart (Henkel 2003). Similar to the water transparency measurements, surface water samples were collected using a $500-\mathrm{mL}$ plastic bottle from the same three spots, and averaged to obtain the daily mean values for each 1-ha plot. The water samples were analysed for five additional water quality parameters; $\mathrm{pH}$, conductivity (ms/ $\mathrm{cm})$, total dissolved solids ( $\mathrm{g} / \mathrm{L})$, salinity (\%o) and turbidity (NTU). Thus, for each of the six water quality parameters, means were obtained for each wetland site, based on the 12 spatio-temporal sample data points (four 1-ha plots $\times 3$ days).

\section{Estimation of abundance of plunge-diving birds}

The abundance of the two plunge-divers was determined in each of the four 1-ha plots. This involved counting birds on an hourly basis four times per day from 07:00 to 10:00 $\mathrm{h}$ in each of the four plots over three days of observation. Thus, for each 1-ha plot, the mean of the four hourly counts was taken as representing the day-specific abundance as birds per hour ( $n=4$ counts). For each of the four 1-ha plots this systematic sampling produced abundance estimates (in birds/h) per each of the three study days per plot, hence 3 days $\times 4$ plots $=12$ spatio-temporal sample data points per wetland. For Pied Kingfishers, that were found at both wetlands this produced 24 data points, whereas for Common Terns, that were undetected at Weija, 12 sample data points were produced. These day-wise abundances could then be directly compared with daily concurrent measurements of water transparency/turbidity. The field data collection was carried out by two observers who worked on the same days and visited all 1-ha plots on a rotational basis. Counting was done by the aid of $10 \times 40 \mathrm{~mm}$ binoculars.

\section{Estimation of prey capture success of plunge-diving birds}

Prey capture success data was taken as described by Taylor (1983) with minor modifications. Any distinctively and determined initiation of a dive towards the water was recorded as a capture attempt and included cases where failure occurred before the bird reached the water as well as those that failed in the water. A dive which resulted in a fish being removed from the water was noted as being successful regardless of whether the fish was later dropped or not during handling.

Immediately after counting birds on the hour within each of the 1-ha plots for the estimation of abundance, the foraging birds were observed continuously for the next $30 \mathrm{~min}$. Thus, for each plot, birds were observed for 30 min after a count on each of the hours between 07:00-10:00 producing a total of $120 \mathrm{~min}$ of observation and 360 min during the 3 days of observation. During each 30-min observation period, the number of capture attempts, number of successful captures and the type of dive were recorded for each plunge-diver. Thus, within each of the four 1-ha plots, mean prey capture success was estimated as the ratio (in \%) of successful attempts to the total number of attempts. The field data collection was carried out by two observers who worked on the same days and visited all plots on a rotational basis, and observation were done by the aid of $10 \times 40 \mathrm{~mm}$ binoculars. As all field data were collected over 12 sample data points ( 4 plots $\times 3$ days) the measurements of prey capture success (\%), bird abundance (birds/h) and water 
quality parameters for each species were compared and relationships analysed.

\section{Data analysis}

Water quality data were analysed with descriptive statistics across the four plots within the three days of data collection for both study sites (i.e. $n=4$ plots $\times 3$ days $=12$ samples per site) including mean, standard deviation and range. In order to determine whether the relationships between water clarity, the abundance and prey capture success of plunge divers were significant, the concurrently taken pair-wise measurements of water quality parameters (i.e. turbidity and transparency) versus plunge-diving observations of each species (i.e. abundance and capture success) were plotted on $X Y$-scatter plots, and linear (GLM) regression lines with Pearson's correlation coefficients $(r)$ were fitted using Microsoft Excel $^{\circledR}$. Significance level of $r$ was set at $\alpha=0.05$, for $\mathrm{df}=n-2$ (two-tailed).

\section{Results}

\section{Species of plunge-diving birds recorded}

Three species of plunge-diving birds, namely Pied Kingfisher (Ceryle rudis), Malachite Kingfisher (Alcedo cristata) and Common Tern (Sterna hirundo) were identified during the study period. The two species of kingfishers were found at both Densu and Weija ( $n=24$ samples), whereas Common Terns were only found at the former $(n=12)$. However, the activities of Malachite Kingfishers were rarely observed during the period of the study and therefore it was not included in the comparative data analysis of water clarity versus abundance and prey capture success. Pied Kingfishers mostly foraged using the partial plunge-diving technique whereas Common Terns predominantly foraged using contact dip technique. Pied Kingfishers mostly engaged in plunging from hovering position (hover-plunging) and less often from perchplunging from a pole in or a branch above the water, whereas Common Terns foraged exclusively by hoverplunging. Common Terns mostly foraged singly albeit also in small flocks, whereas Pied Kingfishers both solitarily and gregariously in small family parties, the latter often observed in large breeding colonies and wandering formations at Densu (Dowsett-Lemaire and Dowsett 2014).

\section{Water quality parameters}

Mean transparency and turbidity were respectively $46 \%$ higher and $\sim 72 \%$ lower in Weija compared to Densu, whereas conductivity and dissolved solids were approximately 30 times higher in Densu compared to Weija (Tables 1,2 ). The relatively low water clarity at Densu indicates that this estuarine waterbody has higher contents of suspended particles and dissolved solids compared with Weija. The Densu estuary has brackish $(7.08 \pm 9.37 \%$ ) and slightly alkaline $(\mathrm{pH}=7.83 \pm 0.84)$ water, compared to the freshwater Weija reservoir, with much lower salinity $(0.19 \pm 0.03 \%)$ and $\mathrm{pH}(6.25 \pm 0.75)$. As expected, concurrent measurements of water transparency and turbidity showed a highly significant $(p<0.001)$ negative correlation, indicating that samples were taken with few errors (Fig. 2).

\section{Water clarity versus abundance and capture success of Pied Kingfishers}

The mean daily abundance of Pied Kingfishers $(2.8 \pm 1.2$; range $=1.3-6.3 \mathrm{birds} /$ hour) was neither correlated with water transparency (Fig. 3a) nor turbidity (Fig. 3b), suggesting that the abundance of Pied Kingfishers was not related to water clarity in both Densu and Weija (Table 3). In relation to prey capture success, mean prey capture success of Pied Kingfishers was $34.7 \pm 13.1 \%$ (range 16.7$75.0 \%$ indicating a success rate of about one out of three attempts. In contrast to the relationship between transparency and turbidity to the abundance of Pied Kingfisher, prey capture success was significantly $(r=0.709$, $p=0.0001, \mathrm{df}=22)$ negatively correlated with transparency (Fig. 3a), and significantly $(r=0.660, p=0.0004$, $\mathrm{df}=22$ ) positively correlated with turbidity (Fig. 3b), indicating that Pied Kingfishers foraged more efficiently with decreasing water clarity. Thus, the spatio-temporal sample points with lower water clarity did not negatively affect abundance of Pied Kingfishers, i.e. the higher turbidity was not a hindrance for effective foraging. Rather, foraging appeared to be more efficient in relatively more turbid waters.

\section{Water clarity versus abundance and capture success of Common Terns}

The mean daily abundance of Common Terns $(5.1 \pm 5.2$; range $=0-17.0$ birds $/ \mathrm{h})$ was significantly $(r=0.660$, $p=0.0195, \mathrm{df}=10)$ and negatively correlated with transparency, just as it was significantly $(r=0.814, p=0.0013$, $\mathrm{df}=10$ ) and positively correlated with turbidity (Table 3 ; Fig. 4a, b), suggesting that terns were relatively more associated with turbid water of lower clarity. Mean prey capture success of Common Terns was $35.3 \pm 11.0 \%$ (range 18.2-55.6\%) indicating a success rate of about one in three attempts. Contrary to abundance, the prey capture success of Common Terns was neither related to water transparency nor to turbidity, suggesting that foraging efficiency of Common Terns was not related to water clarity (Table 3; Fig. 4a, b). 
Table 1 Data on water quality parameters collected at four quadrats (=100 $\mathrm{m} \times 100 \mathrm{~m}$ plots) in Densu Delta Ramsar Site (DDRS) and Weija Lake (WL)

\begin{tabular}{|c|c|c|c|c|c|c|c|}
\hline Study site & Plot no. & Transparency $(\mathrm{cm})$ & $\mathrm{pH}$ & $\begin{array}{l}\text { Conductivity (ms/ } \\
\mathrm{cm})\end{array}$ & Turbidity (NTU) & TDS (mg/L) & Salinity (\%o) \\
\hline DDRS & 1 & 44 & 8.77 & 23.13 & 41 & 14.12 & 13.85 \\
\hline DDRS & 2 & 37 & 8.84 & 18.43 & 41 & 11.24 & 10.82 \\
\hline DDRS & 3 & 32 & 8.42 & 38.50 & 52 & 23.48 & 24.37 \\
\hline DDRS & 4 & 42 & 8.56 & 40.07 & 53 & 24.30 & 25.48 \\
\hline DDRS & 1 & 16.5 & 6.63 & 2.96 & 135 & 1.89 & 1.50 \\
\hline DDRS & 2 & 23 & 6.81 & 2.82 & 129 & 1.89 & 1.53 \\
\hline DDRS & 3 & 16 & 6.91 & 2.98 & 132 & 1.89 & 1.53 \\
\hline DDRS & 4 & 15 & 7.08 & 2.67 & 146 & 1.69 & 1.38 \\
\hline DDRS & 1 & 41 & 8.67 & 1.75 & 82 & 1.09 & 0.88 \\
\hline DDRS & 2 & 33 & 7.38 & 0.61 & 70 & 0.38 & 0.30 \\
\hline DDRS & 3 & 30 & 7.72 & 3.37 & 79 & 2.14 & 1.73 \\
\hline DDRS & 4 & 39 & 8.19 & 3.07 & 103 & 1.96 & 1.60 \\
\hline WL & 1 & 42 & 5.95 & 0.43 & 55 & 0.28 & 0.2 \\
\hline$W L$ & 2 & 42 & 6.85 & 0.42 & 47 & 0.27 & 0.2 \\
\hline WL & 3 & 48 & 6.91 & 0.38 & 58 & 0.24 & 0.2 \\
\hline WL & 4 & 35 & 7.13 & 0.41 & 52 & 0.26 & 0.2 \\
\hline WL & 1 & 41 & 6.67 & 0.38 & 58 & 0.27 & 0.2 \\
\hline WL & 2 & 41 & 6.85 & 0.4 & 55 & 0.26 & 0.2 \\
\hline WL & 3 & 45 & 7.25 & 0.38 & 54 & 0.24 & 0.2 \\
\hline WL & 4 & 42 & 7.5 & 0.38 & 56 & 0.21 & 0.2 \\
\hline WL & 1 & 51 & 5.53 & 0.39 & 37 & 0.25 & 0.2 \\
\hline WL & 2 & 48 & 6.64 & 0.38 & 40 & 0.25 & 0.2 \\
\hline WL & 3 & 50 & 7.46 & 0.33 & 48 & 0.21 & 0.2 \\
\hline$W L$ & 4 & 50 & 7.53 & 0.30 & 59 & 0.19 & 0.1 \\
\hline
\end{tabular}

Each figure represents the mean of three water samples taken haphazardly on the same work days; 3 days at each site

Table 2 Summary of water quality parameters collected at the Densu Delta Ramsar Site and Weija Lake, south-east coastal Ghana

\begin{tabular}{|c|c|c|c|c|}
\hline \multirow[t]{2}{*}{ Water quality parameters } & \multicolumn{2}{|c|}{ Densu Delta Ramsar Site } & \multicolumn{2}{|l|}{ Weija Lake } \\
\hline & Range & Mean \pm SD & Range & Mean \pm SD \\
\hline $\mathrm{pH}$ & $6.63-8.84$ & $7.83 \pm 0.84$ & $5.00-7.00$ & $6.25 \pm 0.75$ \\
\hline Salinity (\%o) & $0.30-25.4$ & $7.08 \pm 9.37$ & $0.10-0.20$ & $0.19 \pm 0.03$ \\
\hline Conductivity (ms/cm) & $0.61-40.07$ & $11.70 \pm 14.70$ & $0.30-0.43$ & $0.38 \pm 0.04$ \\
\hline Total dissolved solids (g/L) & $0.38-24.30$ & $7.17 \pm 8.91$ & $0.19-0.28$ & $0.24 \pm 0.03$ \\
\hline Transparency (cm) & $15.00-44.00$ & $30.70 \pm 10.66$ & $35.00-51.00$ & $44.58 \pm 4.87$ \\
\hline Turbidity (NTU) & $41.00-146.00$ & $88.58 \pm 39.07$ & $37.00-59.00$ & $51.58 \pm 7.18$ \\
\hline
\end{tabular}

Mean \pm SD values obtained from 3 replicate samples on the same day ( $\sim$ the daily mean) within 4 plots of 1 ha in each wetland on 3 different days ( $n=4$ plots $\times 3$ days $=12$ spatio-temporal samples)

\section{Discussion}

Water quality in relation to the two distinct ecosystem types

Densu had a comparatively higher ion load than Weija, which appeared to impact water clarity negatively at the former. As Densu is a brackish water body compared to the freshwater of Weija, some of the ions may be attributed to the higher salinity of the former. This is particularly important as salts may leak into Densu from the adjacent Pambros saltpans. The 30-fold higher TDS and conductivity at Densu compared to Weija are therefore largely attributed to ion loads derived from water soluble 


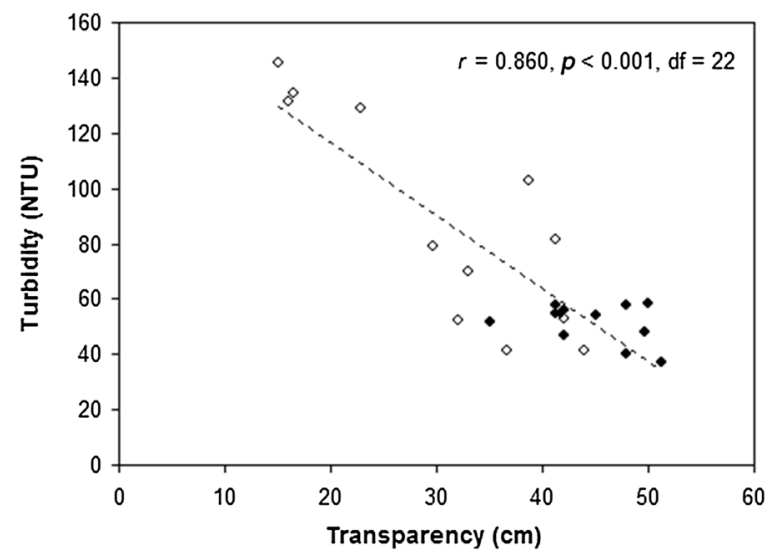

Fig. 2 Relationship between turbidity (NTU) and transparency (cm) for the 24 samples at Lake Weija ( $n=12$, black circles) and Densu Delta Ramsar Site ( $n=12$, open circles), south east coastal Ghana
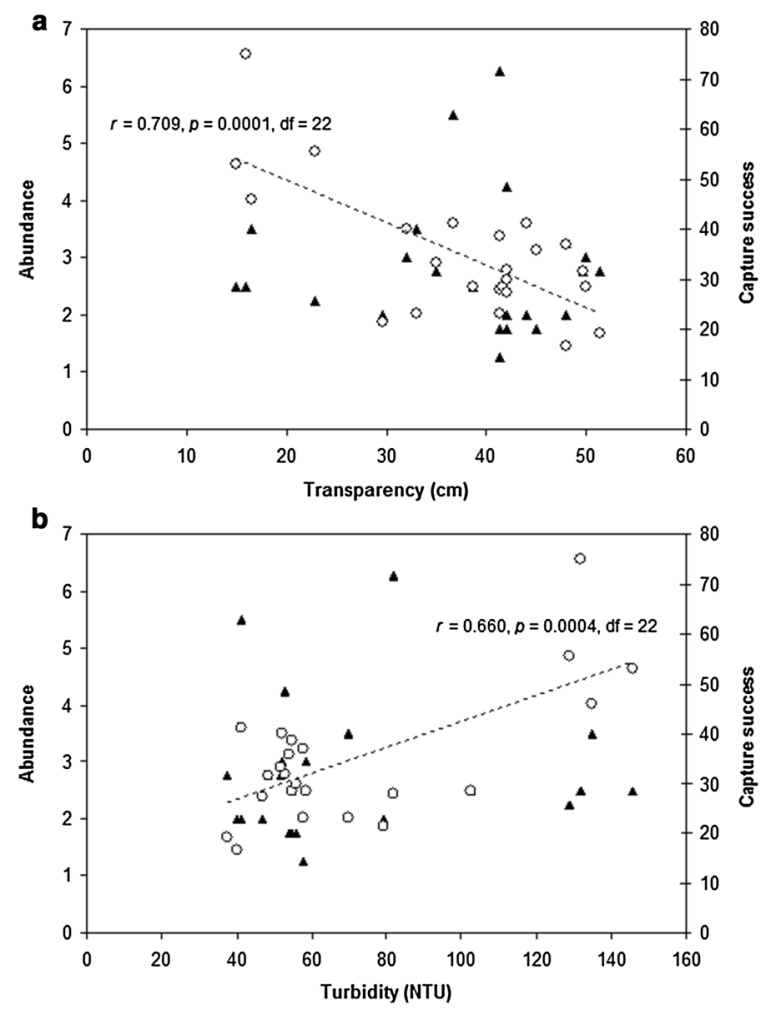

Fig. 3 Water transparency (a) and turbidity (b) in relation to abundance (mean number of birds per hourly count; black triangles) and capture success (\%= successful captures/total attempts; white circles) of Pied Kingfishers in Densu and Weija $(n=24)$, south-east coastal Ghana. The linear $(y=a x+b)$ regression lines shown are for the significant negative relationship between transparency and capture success (a), and the significant positive relationship between turbidity and capture success $(\mathbf{b})$ salts. This notwithstanding, Densu recorded substantially higher turbidity and lower transparency compared to Weija. Turbidity in wetlands is primarily related to eutrophication-induced phytoplankton blooms associated with fertilizer and sewage discharges, as well as suspended soil particles derived from surrounding erosion (Asante et al. 2008). In this regard, Densu is close to several large suburbs of Accra, and therefore serves as a recipient of domestic sewage emanating from these townships. Also, the waters of Densu are shallow as a result of which the activities of fishermen cause perturbations that increase turbidity. Thus the relatively low water clarity at Densu may be attributed to high levels of phytoplankton caused by eutrophication, as well as suspended soil particles resulting from surrounding erosion and perturbations from intensive fishing activities. Although Weija had relatively higher transparency and lower turbidity than Densu, it is worth noting that the mean transparency value recorded in this study at Weija $(35-51 \mathrm{~cm})$ is considerably lower than the $71 \mathrm{~cm}$ reported for the same habitat in the mid to late 1990s (Ansa-Asare and Asante 2005). Thus, just as Densu is close to human settlements and receives pollutants, Weija is also increasingly becoming polluted from increasing anthropogenic activities and disturbances in its catchment.

\section{Abundance of plunge-divers in relation to water clarity}

We observed that Pied Kingfishers mostly used partial plunge-diving whereas Common Terns almost always used contact dipping, hence indicating that each species responded differently to water clarity. Our results suggest that the abundance of Pied Kingfishers is largely independent on water clarity, whereas Common Terns appeared to be more abundant in less transparent (more turbid) water. Both results indicate that the water clarity did not negatively affect abundances of the two species of plunge-divers. Nevertheless, the range of transparency detected in our study was relatively low $(15-51 \mathrm{~cm})$ and therefore, the probability of kingfishers and terns frequenting clearer water if they were available cannot be overruled.

Similar to the findings of our study, no relationship was observed between water clarity and the abundance of Pied Kingfisher, Malachite Kingfisher, Giant Kingfisher (Megaceryle maximus) and Half-Collared Kingfisher (Alcedo semitorquata) in the Wilderness Complex Lakes of South Africa (Russell et al. 2014). However, Borah (2011) found turbidity to be negatively associated with occupancy of two piscivorous plunge-divers, namely Common (Alcedo atthis) and Brown-winged 
Table 3 Data collected on relative abundance $(R A=$ birds counted per hour) and capture success $(C S=$ successful attempts relative to total attempts, in \%), during $4 \mathrm{~h}$ of work per day in each of 4 quadrats of $100 \mathrm{~m} \times 100 \mathrm{~m}$ (Plot 1-4), with 3 days each in Densu Delta Ramsar Site (DDRS) and Weija Lake (WL)

\begin{tabular}{|c|c|c|c|c|c|}
\hline \multirow[t]{2}{*}{ Study site } & \multirow[t]{2}{*}{ Plot \# } & \multicolumn{2}{|l|}{ Pied Kingfisher } & \multicolumn{2}{|l|}{ Common Tern } \\
\hline & & RA (birds/hour) & CS (\%) & RA (birds/hour) & CS (\%) \\
\hline DDRS & 1 & 2.0 & 41.2 & 0 & - \\
\hline DDRS & 2 & 5.5 & 41.2 & 0.5 & 22.2 \\
\hline DDRS & 3 & 3.0 & 40.0 & 0 & - \\
\hline DDRS & 4 & 4.3 & 31.8 & 1.5 & 33.3 \\
\hline DDRS & 1 & 3.5 & 45.9 & 17.0 & 29.3 \\
\hline DDRS & 2 & 2.3 & 55.6 & 3.8 & 43.5 \\
\hline DDRS & 3 & 2.5 & 75.0 & 6.5 & 41.8 \\
\hline DDRS & 4 & 2.5 & 52.9 & 11.5 & 34.8 \\
\hline DDRS & 1 & 6.3 & 27.8 & 4.3 & 31.3 \\
\hline DDRS & 2 & 3.5 & 23.1 & 1.8 & 55.6 \\
\hline DDRS & 3 & 2.0 & 21.4 & 4.8 & 42.9 \\
\hline DDRS & 4 & 2.5 & 28.6 & 9.3 & 18.2 \\
\hline$W L$ & 1 & 2.5 & 28.6 & - & - \\
\hline$W L$ & 2 & 2.0 & 27.3 & - & - \\
\hline$W L$ & 3 & 3.3 & 36.8 & - & - \\
\hline$W L$ & 4 & 2.8 & 33.3 & - & - \\
\hline$W L$ & 1 & 1.3 & 23.1 & - & - \\
\hline$W L$ & 2 & 1.8 & 38.5 & - & - \\
\hline$W L$ & 3 & 1.8 & 35.7 & - & - \\
\hline$W L$ & 4 & 1.8 & 30.0 & - & - \\
\hline WL & 1 & 2.8 & 19.0 & - & - \\
\hline$W L$ & 2 & 2.0 & 16.7 & - & - \\
\hline$W L$ & 3 & 2.8 & 31.6 & - & - \\
\hline$W L$ & 4 & 3.0 & 28.6 & - & - \\
\hline Mean \pm SD & - & $2.8 \pm 1.2$ & $34.7 \pm 13.1$ & $5.1 \pm 5.2$ & $35.3 \pm 11.0$ \\
\hline
\end{tabular}

Note that Common Terns were not observed at WL, hence $n=12 . \mathrm{RA}=$ birds counted per hour; $\mathrm{CS}=$ successful attempts relative to total attempts, in $\%$

Kingfisher (Pelargopsis amauroptera), at the Bhitarkanika mangroves, east coast of India. Both Indian kingfishers use partial or full plunge-dive, and apparently need clear water in the estuary to forage in this way. Similarly, Anderson et al. (2013) found water transparency to be positively correlated with the abundance of Belted Kingfisher (Ceryle alcyon) on the Ohio River. Pied Kingfishers have relatively large body size and apply several modes of foraging from both perching or hovering (Reyer et al. 1988; Johnston 1989), and can reach deeper than smaller species when performing full plunge-dive (Bonnington et al. 2008). The fact that we mostly observed partial plunging in this species may be an indication that water transparency was too low for full plunge-dive.

Several species of tern including Common Terns are known to prefer foraging in more turbid water (e.g. Haney and Stone 1988; Safina and Burger 1988; Cyrus 1991; Henkel 2006; Russell et al. 2014) and this is consistent with our findings from Densu. Haney and Stone
(1988) hypothesized that abundance of plunge-divers off the coast of the south-eastern USA, should increase with an increasing transparency (i.e. decreasing turbidity) gradient, but found that only one plunge-diving species was significantly more common in clear water whereas five species (including Common Tern and three other terns) were observed with higher densities in more turbid water. According to Cyrus (1991), rather than the turbidity itself, fish density associated with out flowing river debris of detritus and macrophytes attracted Little Terns in South African estuaries to the interface between the brackish plume of turbid estuarine water and the clear marine shore. Other predators were attracted to this contrasting turbidity plume interface, including Bluefish (Pomatomus saltatrix), a predatory fish that has been shown to be implicated in interspecific competitive interactions among Roseate and Common Terns (Safina 1990b). 

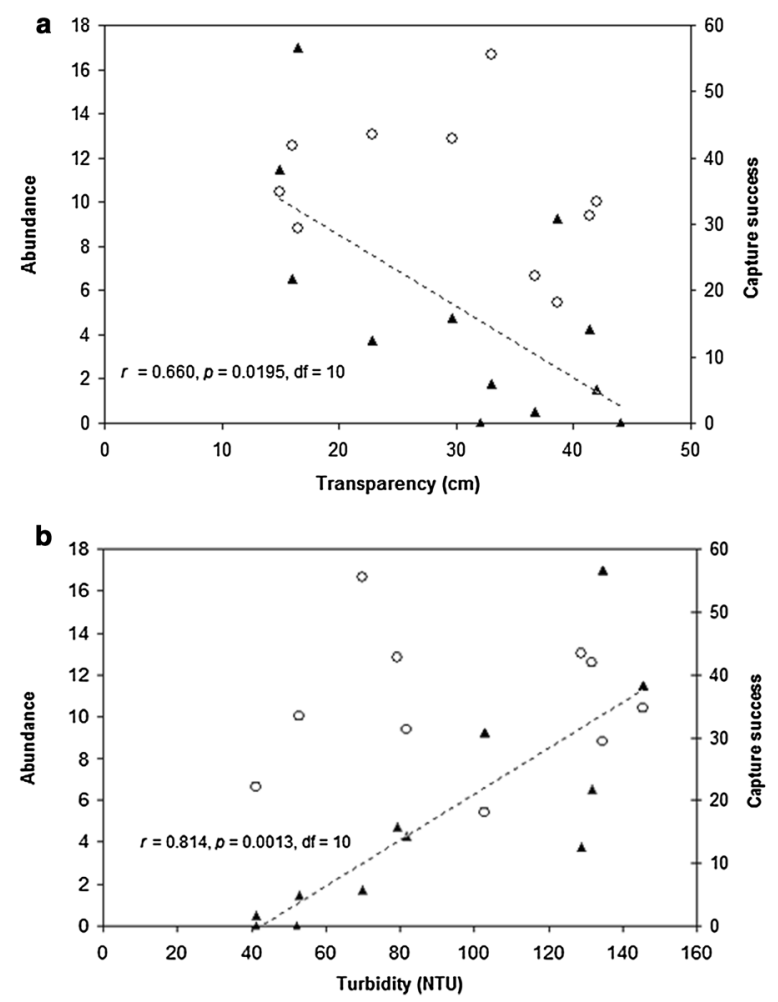

Fig. 4 Water transparency (a) and turbidity (b) in relation to abundance (mean number of birds per hourly count; black triangles) and capture success (\%= successful captures/total attempts; white circles) of Common Terns in Densu Delta Ramsar Site $(n=12$; two quadrats had no observations of terns, wherefore correlations between respectively turbidity and transparency as against capture success applied only $n=10$ data points), south-east coastal Ghana. The linear $(y=a x+b)$ regression lines shown are for the significant negative relationship between transparency and abundance (a), and the significant positive relationship between turbidity and abundance (b)

In line with the above, abundance of plunge-divers depends on a multitude of factors, of which some may be interrelated. Prey density and abundance are crucial factors (e.g. Davoren et al. 2003; Newbrey et al. 2005; Enstipp et al. 2007), but also and perhaps more importantly the availability or accessibility of prey, of which the latter may depend on water clarity as well as speciesspecific foraging habits and anti-predator behaviour of various prey. Hence, a lower density of prey may be compromised by higher visibility of prey, so far as prey can be reached during the plunging (Eriksson 1985). According to Katzir and Camhi (1993) fish prey may not see the predator coming in turbid waters, unlike in clear waters where fish prey may detect an approaching predator and try to escape. Safina and Burger (1988) also observed that fish prey normally avoids the surface, and that they tend to swim deeper at increasing water transparency, which in effect increases their chances of escape from diving predators. Sohel and Lindström (2015) confirmed that algal turbidity has detrimental effects on the ability of Three-spined Sticklebacks (Gasterosteus aculeatus) to assess predation risk from avian predators such as Common Terns, and therefore, rendering fish more vulnerable to avian predation under turbid conditions in shallow waters. Abundance of plunge-divers is therefore determined by a complex interrelationship among environmental parameters, including water clarity, as well as competition and predator-prey relationships (e.g. Abrahams and Kattenfeld 1997).

\section{Prey capture success of plunge-divers in relation to water clarity}

Pied Kingfishers at Densu and Weija used mostly hoverplunging (c. 4 out of 5 attempts) although when tall perches were available they used perch-plunging. It is known that both wind and the availability of perches will affect the choice between hover and perch-plunging (Cramp et al. 1988; Johnston 1989). Due to lack of perches and windy conditions, our estimates of prey capture success were therefore primarily based on hoverplunging observations. Comparatively, the rate of prey capture success of Pied Kingfishers observed in this study $(34.7 \pm 13.1 \%)$ was higher than those reported for the same species from the polluted Okavango Delta (9.011.3\%) in Botswana (Douthwaite 1982), and Lake Malawi (18\%) by Johnston (1989). In contrast, our estimated rate of prey capture success of Pied Kingfishers was lower than those reported for the same species in lakes Kariba in Zimbabwe (Junor 1972) and Victoria in Uganda (Douthwaite 1976), both of which ranged between 40 and $50 \%$. The relatively higher rate of prey capture success of Pied Kingfishers in lakes Kariba and Victoria may possibly be attributed to clearer water in the lakes during the 1960-70 s, compared to the 1980s. These comparisons indicate that our estimates of capture success fall within the range of those reported for relatively polluted (Douthwaite 1982; Johnston 1989) to cleaner (Junor 1972; Douthwaite 1976) water in Africa, and therefore highlighting the scientific accuracy and precision of our data. Further, the above comparison of our estimates of capture success in relation to water clarity, with other African studies also highlights the implications of water pollution for effective foraging of Pied Kingfishers.

The prey capture success estimated for Common Terns in our study was very close to those reported from Royal Terns (Sterna maxima) (38\%) in Netherland Antilles (Buckley and Buckley 1974), and Damara Terns (S. balaenarum) (35.3\%) in Southern Namibia (Braby et al. 2011), as well as within the range (15-52\%) recorded for Roseate Terns in Massachusetts, USA (Watson and Hatch 1999). 
Sandwich and Roseate Terns foraging in the temperate zone (south eastern Dutch North Sea) as well as close to the equator (Puerto Rico), on the other hand have been found to reach significantly higher prey capture success, ranging from 54 to $71 \%$ depending on age, water depth and clarity (Shealer and Burger 1995; Baptist and Leopold 2010). However, our estimates for Common Terns are much higher than those recorded for Sandwich Terns in our region; Sierra Leone and Guinea-Bissau, ranging from 12 to 17\% (Dunn 1972a; Stienen and Brenninkmeijer 1994) as well as for Namibia of $14 \%$ (Simmons and Braine 1994). These data indicate that foraging success may not be detrimentally affected by the prevailing conditions at Densu as compared to other tropical regions, including the Afrotropics.

We found that prey capture success of Pied Kingfishers increased with decreasing transparency at both wetlands, suggesting that they forage more efficiently in more turbid waters. This finding is in line with those suggested by Reyer et al. (1988) in which foraging efficiency of Pied and Malachite Kingfishers reduced as water clarity increased. In contrast to Pied Kingfishers, our study indicated that prey capture success of Common Terns was independent of water clarity at Densu. The prey capture success of a number of tern species including Sandwich and Royal Terns (Thalasseus maxima) (Brenninkmeijer et al. 2002) were reported to increase with water clarity. Comparatively however, Brenninkmeijer et al. (2002) assessed a transparency gradient of 0.2 to $3.25 \mathrm{~m}$ which is far broader than that recorded in our study. Similarly, in reporting that Damara Terns dived for prey more successfully in the least turbid water, Braby et al. (2011) indicated that the clearest water in their study was relatively murky. Braby et al. (2011) therefore proposed that prey capture success may decrease if the water was very clear, indicating a non-linear relationship between water transparency and capture success, as has been found in Sandwich Terns in the temperate zone (Baptist and Leopold 2010). Therefore, compared to these studies the range of water clarity of our study area was relatively low and may have implications for the results.

The prey capture success of plunge-divers in relation to water clarity depends on the importance of anti-predator relationships to the total outcome of predator-prey interactions (Abrahams and Kattenfeld 1997). In this regard, the efficiency with which the avian predator detect prey and maintain the visibility during attack, as well as the efficiency of the prey detecting and maintaining visibility of the predator are paramount (Recher and Recher 1972). Thus, as water clarity decreases, the efficiency of both predator and prey in detecting each other will decrease, and the success of predation will depend on whether the prey is able to escape attack as well as whether the predator is fast enough to surprise and capture the prey. In effect, if water is very turbid, as in our study areas, fish prey may benefit from moving in the surface water with reduced probability of being detected from above by plunge-divers (e.g. Forsell 1983; Henkel 2006) but this will come at the expense of a compromised ability of the prey in detecting attacking predators, thereby increasing predation risk (e.g. Katzir and Camhi 1993).

This notwithstanding, it is well known that the ability of fish prey to respond to avian predators is constrained by high turbidity such that prey is more vulnerable at high turbidity levels both in terms of choosing less dangerous habitat (Abrahams and Kattenfeld 1997) and escaping predator attacks (Sohel and Lindström 2015). Flemming and Smith (1990) reported the prey capture success of Ospreys to be higher in turbid waters because prey move closer to the surface making them more available to attack from above. Thus, our observations of Common Terns being more attracted to turbid spatiotemporal sample plots, and the fact that Pied Kingfishers foraged more efficiently in less transparent waters may be attributed to the prey's higher vulnerability as water clarity decreases.

In relation to prey capture rate and capture success, Braby et al. (2011) reported a negative relationship between capture rate and capture success for Damara Terns under difficult foraging conditions. It was interpreted that the terns made fewer attempts under difficult conditions but were more successful because the attempts were made only when the chance of successful capture was high. In our study, correlations between capture success as against respectively total capture attempts and capture attempts per individual per hour for both plunge-divers were not significant. The implication of this is that a higher fish abundance which most likely reflects a higher rate of capture attempts, does not translate to higher capture success. Further, if abundances of plunge-divers are primarily driven by higher fish abundances, this does not explicitly mean that birds forage more efficiently where fishes are most abundant. Similarly, we found no positive correlations between the abundance of plunge-diving birds versus capture success. Therefore, if plunge-divers are attracted to spatiotemporal sample plots with higher fish abundance but are not rewarded with increased capture success rates, then the birds would not be disadvantaged if they are equally attracted to areas with lower fish abundance (e.g. in less turbid waters) that offer increased chances of successful strikes (Eriksson 1985). Our data did not readily support the hypothesis that higher fish abundance driven by higher turbidity will explicitly draw birds to such areas due to ease of catching prey during plunging, but perhaps as a result of higher prey detection probability where fish 
abundance is relatively high. However, if fishes are more abundant and easily detected in turbid waters, they can only be efficiently captured in the surface where they are readily visible. Baptist and Leopold (2010) reported that Sandwich Terns adjusted their diving technique in response to water transparency such that full plunge-dive is dominantly applied in clear waters while partial plunging and contact dipping were applied more frequently in turbid waters. In our study, neither the Pied Kingfisher, nor the Common Tern engaged in full plunging and this could be attributed to the extent of turbidity prevailing at Densu and Weija, which probably limits the efficient use of this foraging technique.

Our study covered both the end of the major dry season (March) and beginning of the major wet season (April), and we anticipate that water clarity was relatively low in this 2-months period due to a combination of high temperatures and low water levels. Although water clarity may increase towards the peak rainy season, due to higher water levels, the opposite could equally be the case as terrestrial leaching of nutrients from farms and landfills would cause eutrophication when precipitation is high. Indeed, the very high turbidity levels recorded at this time of the year are most likely sustained due to low water replacement and high nutrient influx throughout the year in both wetlands. We recognize that this study was short-term with a relatively small sample size, but that most trends in the data sets are far too significant $(p<0.02)$ to attribute only to statistical errors, at least in the sense that low water clarity is not a hindrance for the presence and performance of two species of plunge-diving birds that mostly engage in contact dipping and partial plunging in the upper layers of the water column.

\section{Conclusions}

This study indicated that the relatively narrow water clarity gradient prevailing at Densu and Weija did not significantly impair efficient foraging of Pied Kingfisher and Common Tern. Although the prey capture success of the two species of plunge-divers were similar, Common Terns were significantly more abundant in less transparent/more turbid waters while Pied Kingfisher abundance showed no significant relationship with turbidity and transparency. Prey capture success of Common Tern was neither related to transparency nor turbidity, as opposed to that of Pied Kingfisher which was significantly higher in more turbid/less transparent waters. Full plunge-dive was not observed among any of the two species and therefore suggesting the turbidity prevailing at Densu and Weija probably limited the efficient use of this foraging technique. We suggest that based on the importance of anti-predator relationships to the total outcome of predator-prey interactions, less transparent/more turbid waters promote higher fish abundance which drives higher abundance and capture attempts of the plunge divers, albeit not capture success. Thus the high abundance of Common Terns in spatio-temporal sample plots with more turbid water, and the fact that Pied Kingfishers foraged more efficiently in less transparent waters may be as a result of better fish prey detection in upper surface layers of the water column as well as higher fish prey vulnerability here. Hence, our data show that abundances of plunge-divers are not driven by higher capture success, but rather that fish prey are only detected in surface layers, in which birds may have an advantage in higher detectability of prey (mainly cichlids) as opposed to lower predator avoidance by these fish. It appears therefore that even though capture success is not higher where birds are more abundant, the mere fact that fishes are predominantly detected in surface water most likely drives higher abundances of plunge-divers, rather than high foraging efficiency.

\section{Authors' contributions}

Fieldwork designed and data analysed by LHH. Field data collected by TKA supervised by LHH/FG. Manuscript drafted by LHH/TKA; revised by FG. All authors read and approved the final manuscript.

\section{Author details}

${ }^{1}$ Department of Animal Biology and Conservation Science, University of Ghana, P.O. Box LG 67, Legon, Accra, Ghana. ${ }^{2}$ Department of Biodiversity Conservation and Management, University for Development Studies, Box TL 1882, Nyankpala Campus, Tamale, Ghana.

\section{Acknowledgements \\ We thank two anonymous reviewers for valuable contributions to the manuscripts.}

\section{Competing interests}

The authors declare that they have no competing interests.

\section{Availability of data and materials}

The datasets used in this study can be provided by the corresponding author on reasonable request.

\section{Consent for publication}

Not applicable.

\section{Ethics approval and consent to participate}

The fieldwork complies with the current laws and regulations of Ghana in which they were conducted.

Funding

Not applicable (self-funding).

Received: 13 December 2017 Accepted: 6 July 2018

Published online: 16 July 2018

\section{References}

Abrahams M, Kattenfeld M. The role of turbidity as a constraint on predator-prey interactions in aquatic environments. Behav Ecol Soc. 1997:40:169-74. 
Ahulu AM, Nunoo FKE, Owusu EH. Food preferences of the common tern, Sterna hirundo (Linnaeus, 1758) at the Densu floodplains, Accra. West Afr J Appl Ecol. 2006;9:1-7.

Anderson JT, Zadnik AK, Wood PB, Bledsoe K. Evaluation of habitat quality for selected wildlife species associated with island back channels. Open J Ecol. 2013;3:301-10.

Ansa-Asare OD, Asante KA. A comparative study of the nutrient status of two reservoirs in southeast Ghana. Lakes Reserv Res Manag. 1998;3:205-17.

Ansa-Asare OD, Asante KA. Changes in the chemistry of the Weija Dam Reservoir in Ghana, twenty years after impoundment. West Afr J Appl Ecol. 2005;8:35-47.

Asante KA, Quarcoopome T, Amevenku FYK. Water quality of the Weija reservoir after 28 years of impoundment. West Afr J Appl Ecol. 2008;13:125-31.

Baptist MJ, Leopold MF. Prey capture success of Sandwich Terns Sterna sandvicensis varies non-linearly with water transparency. Ibis. 2010;152:815-25.

BirdLife Int. Important Bird Areas factsheet: Densu Delta Ramsar Site and vicinity. 2018. Downloaded from http://www.birdlife.org on Accessed 07 Mar 2018.

Bonnington C, Weaver D, Fanning E. The habitat preference of four kingfisher species along a branch of the Kilombero River, southern Tanzania. Afr J Ecol. 2008;46:424-7.

Borah J. Occupancy pattern and food-niche partitioning among sympatric kingfishers in Bhitarkanika mangroves, Orissa. MSc Thesis. 2011; Saurashtra Univ. Rajkot, India.

Braby J, Underhill LG, Simmons RE. Prey capture success and chick diet of Damara terns Sterna balaenarum in Namibia. Afr J Mar Sci. 2011;33:225-47.

Brenninkmeijer AE, Stienen WM, Klaassen M, Kersten M. Foraging ecology of wintering terns in Guinea-Bissau. Ibis. 2002;144:602-13.

Briggs KT, Ainley DG, Spear LB, Adams PB, Smith SE. Distribution and diet of Cassin's Auklet and Common Murre in relation to central California upwellings. Proc Int Ornithol Congr. 1988;19:983-90.

Buckley FG, Buckley PA. Comparative feeding ecology of wintering adult and juvenile Royal Terns (Aves: Laridae, Sterninae). Ecology. 1974;55:1053-63.

Cramp S, Douthwaite R, Reyer H, Westerturp K. Pied Kingfisher Ceryle rudis (Linnaeus). In: Fry H, Keith S, Urban E, editors. The Birds of Africa, vol. 3. San Diego: Academic Press; 1988. p. 299-302.

Cyrus DP. The influence of turbidity on the foraging behaviour of Little Terns Sterna albifrons off the St. Lucia Mouth, Zululand, South Africa. Mar Ornithol. 1991;19:103-8.

Davoren GK, Montevecchi WA, Anderson JT. Distributional patterns of a marine bird and its prey: habitat selection based on prey and on specific behaviour. Mar Ecol Prog Ser. 2003;256:229-42.

Douthwaite RJ. Fishing techniques and foods of the pied kingfisher on Lake Victoria in Uganda. Ostrich. 1976;47:153-60.

Douthwaite RJ. Changes in Pied Kingfisher (Ceryle rudis) feeding related to endosulfan pollution from tsetse fly control operations in the Okavango Delta, Botswana. J Appl Ecol. 1982;19:133-41.

Dowsett-Lemaire F, Dowsett RJ. The birds of Ghana. Jupille-Liege: Tauraco Press; 2014. p. 713.

Dunn EK. Studies on terns, with particular reference to feeding ecology. Ph.D Thesis. South Africa: Durham University. 1972a.

Dunn EK. Effect of age on the fishing ability of sandwich terns Sterna sandvicensis. Ibis. 1972;114:360-6.

Elliot A. Family Pelecanidae (Pelicans). In: Handbook of Birds of the World. vol 1. Barcelona: Lynx Editions. 1992.

Enstipp MR, Grémillet D, Jones DR. Investigating the functional link between prey abundance and seabird predatory performance. Mar Ecol Prog Ser. 2007;331:267-79.

Eriksson MOG. Prey detectability for fish-eating birds in relation to fish density and water transparency. Ornis Scand. 1985;16:1-7.

Flemming SP, Smith PC. Environmental influences on Osprey foraging in northeastern Nova Scotia. J Raptor Res. 1990;24:64-7.

Forsell DJ. Predatory efficiency and energetics of Belted kingfishers wintering along the Mad River. MSc Thesis. Humboldt: Humboldt State University. 1983.

Gbogbo F. The importance of unmanaged coastal wetlands to waterbirds at coastal Ghana. Afr J Ecol. 2007:45:599-606.

Gbogbo F, Attuquayefio DK. Issues arising from changes in waterbird population estimates in coastal Ghana. Bird Popul. 2010;10:79-87.
Gbogbo F, Oduro W, Oppong SK. Nature and pattern of lagoon fisheries resource utilisation and their implications for waterbird management in coastal Ghana. Afr J Aquat Sci. 2008:33:211-22.

Gbogbo F, Adaworomah BB, Asante E, Brown-Engmann GR. Human related bird flushes are of little consequence to wintering waterbirds in a tropical coastal wetland in Ghana. Wader Stud Group Bull. 2013;120:60-5.

Grimble R, Ellenbroek W, Willoughby N, Danso E, Ametekpor J. Study of development options for Ghana's wetlands (Vol. 1). Technical report to the Environmental Protection Agency and Natural Resource International. Chatham, Kent; 1998. p. 94

Haney JC. Winter habitat of Common loons on the continental shelf of the Southeastern United States. Wilson Bull. 1991;102:253-63.

Haney JC, Stone AE. Seabird foraging tactics and water clarity: are plunge divers really in the clear? Mar Ecol Prog Ser. 1988;49:1-9.

Henkel LA. The distribution and abundance of marine birds in nearshore waters of Monterey Bay, California.MSc Thesis. California State University, Monterey Bay. 2003.

Henkel LA. Effect of water clarity on the distribution of marine birds in nearshore waters of Monterey Bay, California. J Field Ornithol. 2006;77:151-6.

Johnston DW. Feeding ecology of Pied kingfishers on Lake Malawi, Africa. Biotropica. 1989;21:275-7.

Junor FJR. Offshore fishing by the Pied Kingfisher Ceryle rudis at Lake Kariba. Ostrich. 1972:43:185.

Katzir G, Camhi JM. Escape response of Black Mollies (Poecilia sphenops) to predatory dives of a Pied Kingfisher (Ceryle rudis). Copeia. 1993;2:549-53.

Lamptey AM, Ofori-Danson PK. Review of the distribution of waterbirds in two tropical coastal Ramsar lagoons in Ghana, West Africa. West Afr J Appl Ecol. 2014;22:77-91.

Newbrey JL, Bozek MA, Niemuth ND. Effects of lake characteristics and human disturbance on the presence of piscivorous birds in Northern Wisconsin, USA. Waterbirds. 2005;28:478-86.

Ntiamoa-Baidu Y, Nyame SK, Nuoh AA. Trends in the use of a small coastal lagoon by waterbirds: Muni Lagoon (Ghana). Biodivers Conserv. 2000:9:527-39.

Piersma T, Ntiamoa-Baidu Y. Waterbird ecology and the management of coastal wetlands in Ghana 12. NIOZ Report 1995-1996. 1995. p. 105

Quarcoopome T, Amevenku FYK. Fish community structure of Weija reservoir after 28 years of impoundment. J Appl Sci Technol. 2010;15:126-31.

Recher HF, Recher JA. The foraging behavior of the Reef Heron. Emu. 1972;72:85-90

Reyer H-U, Migongo-Bake W, Schmidt L. Field studies and experiments on distribution and foraging of Pied and Malachite Kingfishers at Lake Nakuru (Kenya). J Anim Ecol. 1988;57:595-610.

Ropert-Coudert Y, Grémillet D, Ryan PG, Kato A, Naito Y, Le Maho Y. Between air and water: the plunge-dive of the cape gannet Morus capensis. Ibis. 2004;146:281-90.

Ropert-Coudert Y, Daunt F, Kato A, Ryan PG, Lewis S, Kobayashi K, Mori Y, Grémillet D, Wanless S. Underwater wingbeats extend depth and duration of plunge dives in northern gannets Morus bassanus. J Avian Biol. 2009:40:380-7.

Russell IA, Randall RM, Hanekom N. Spatial and temporal patterns of waterbird assemblages in the Wilderness Lakes Complex, South Africa. Waterbirds. 2014;37:1-18

Safina C. Foraging habitat partitioning in Roseate and Common terns. Auk. 1990a; 107:351-8

Safina C. Bluefish mediation of foraging competition between Roseate and Common Terns. Ecology. 1990b; 71:1804-9.

Safina C, Burger J. Common Tern foraging: seasonal trends in prey fish densities and competition with bluefish. Ecology. 1985;66:1457-63.

Safina C, Burger J. Ecological dynamics among prey fish, bluefish and foraging Common terns in an Atlantic coastal system. In: Burger J, editor. Seabirds and other marine vertebrates. New York: Columbia University Press; 1988. p. 95-173.

Shealer DA, Burger J. Comparative foraging success between adult and oneyear-old Roseate and Sandwich terns. Colon Waterbirds. 1995;18:93-9.

Simmons RE, Braine S. Breeding, foraging, trapping and sexing of Damara terns in the Skeleton Coast Park, Namibia. Ostrich. 1994:65:264-73. 
Sohel S, Lindström K. Algal turbidity reduces risk assessment ability of the Three-Spined Stickleback. Ethology. 2015;121:548-55.

Stempniewicz L, Darecki M, Trudnowska E, Błachowiak-Samołyk K, Boehnke R, Jakubas D, Keslinka-Nawrot L, Kidawa D, Sagan S, Wojczulanis-Jakubas K. Visual prey availability and distribution of foraging little auks (Alle alle) in the shelf waters of West Spitsbergen. Polar Biol. 2013;36:949-55.

Stienen EWM, Brenninkmeijer A. Voedselecologie van de grote sterns (Sterna sandvicensis): onderzoek ter ondersteuning van een populatie-dynamisch model. Wageningen: Instituut voor Bos- en Natuuronderzoek; 1994 (in Dutch)

Strod T, Izhaki I, Arad Z, Katzir G. Prey detection by great cormorant (Phalacrocorax carbo sinensis) in clear and in turbid water. J Exp Biol. 2008;211:866-72
Taylor IR. Effect of wind on the foraging behaviour of common and sandwich terns. Ornis Scand. 1983;14:90-6.

WRC Ghana. Densu river basin —integrated water resources management plan. Technical Report. Water Resources Commission of Ghana. 2007. p. 83.

Watson MJ, Hatch JJ. Differences in foraging performance between juvenile and adult Roseate Terns at a pre-migratory staging area. Waterbirds. 1999;22:463-5
Ready to submit your research? Choose BMC and benefit from:

- fast, convenient online submission

- thorough peer review by experienced researchers in your field

- rapid publication on acceptance

- support for research data, including large and complex data types

- gold Open Access which fosters wider collaboration and increased citations

- maximum visibility for your research: over $100 \mathrm{M}$ website views per year

At BMC, research is always in progress.

Learn more biomedcentral.com/submissions 